\title{
STUDI MENGENAI BIAYA PENGELOLAAN LINGKUNGAN PADA MASA KONSTRUKSI
}

\author{
Agi R. Hendardi \\ Universitas Perjuangan Tasikmalaya, \\ Jalan Peta No. 177 Kota Tasikmalaya, Kode Pos 46115 \\ email:agirivi@unper.ac.id
}

DOI: http://dx.doi.org/10.29103/tj.v10i2.282

(Received: February 2020 / Revised: August 2020 / Accepted: August 2020)

\begin{abstract}
Abstrak
Dampak lingkungan akibat proyek konstruksi selalu menjadi masalah serius bagi kelangsungan berjalannya proyek konstruksi apabila tidak dilakukan pengelolaannya. Pengelolaan lingkungan pada masa konstruki umumnya tidak dituliskan pada spesifikasi pekerjaan, namun perlu untuk dilakukan. Biaya yang dibutuhkan untuk pengelolaan lingkunan ini sendiri diambil dari persentase biaya tidak langsung proyek. Saat ini ditengarai pihak kontraktor di Kota Tasikmalaya tidak memiliki standar harga satuan pekerjaan untuk pengelolaan lingkungan pada kegiatan proyek konstruksi. Maka dalam penelitian ini akan diidentifikasi pengelolaan dampak lingkungan apa saja yang ditangani oleh pihak kontraktor, dihitung persentase kisaran biaya yang dibutuhkan untuk pengelolaan setiap dampak lingkungan, serta menganalisis pola interaksi besar-kecilnya kisaran biaya pengelolaan lingkungan untuk setiap dampak lingkungan. Penelitian ini menggunakan metode analisis deskriptif dengan teknik pengumpulan data penelitian wawancara dan kuisioner. Pengumpulan data disebarkan ke enam proyek gedung di Kota Tasikmalaya. Dari hasil penelitian di dapatkan bahwa pengelolaan lingkungan yang umum dilakukan oleh pihak kontraktor adalah pengelolaan dampak kebisingan, pengelolaan dampak kuantitas \& kualitas air, pengelolaan dampak lingkungan kotor, dan pengelolaan dampak akses jalan. Kisaran biaya yang dikeluarkan untuk setiap pengelolaan lingkungan ini bervariasi untuk setiap proyek. Faktor-faktor yang mempengaruhi pola interaksi dari kisaran biaya pengelolaan lingkungan tergantung pada karakteristik proyek yang berupa lokasi proyek, nilai proyek, serta spesifikasi pekerjaan pada masing-masing proyek.
\end{abstract}

Kata kunci: Dampak lingkungan, pengelolaan dampak lingkungan, kisaran biaya

\begin{abstract}
The Environmental Impacts Assesment (EIA) of construction projects has always been a serious problem for the continuity of the construction process. Environmental management during the construction period gnerally are not stated in the job specification, which supposed to be done. Costs required for the enviromental management are taken from the percentage of indirect costs of the project. Tasikmalaya's contractor allegedly don't have a standard of unit price for environmental management in construction project activities. This study will identify what kind of environmental impacts management that is handled by Contractor, forecast of percentage costs required for enviromental management impacts, and analyzing the interaction patterns of costs range for every environmental impacts.This research used descriptive analysis with data collection and research interview questionnaire. The collection of data distributed to the six building projects in Tasikmalaya. The result of study shows that environmental management is commonly
\end{abstract}

Studi Mengenai Biaya Pengelolaan Lingkungan Pada Masa Konstruksi - Agi R. 123 Hendardi 


\begin{abstract}
done by the Contractors are : noise pollution management, quality \& quantity of water management, sanitation impact management, and transportation resource management. The range of costs for each environmental management varies for each project. Factors that influence the interaction patterns of the costs range depending on the characteristics of environmental management projects such as location, value, and specifications of the work on each project.
\end{abstract}

Keywords: Environmental Impact, Environmental Impact Management, Cost range

\title{
1. Latar Belakang
}

Industri konstruksi merupakan salah satu pasar yang sangat kompetitif yang dikendalikan oleh harga. Untuk menjaga daya saing, perusahaan konstruksi harus terus berupaya mengurangi biaya proyek sambil secara bersamaan menyediakan produk dan layanan berkualitas kepada klien mereka (Chan, 2012). Biaya merupakan salah satu aspek penting dalam kegiatan proyek konstruksi karena tanpa adanya biaya maka kegiatan konstruksi tidak dapat di realisasikan. Dalam rangka meningkatkan daya saing di industry jasa konstruksi, sangat diperlukan manajemen biaya yang baik dalam pengelolaan proyek.

Biaya proyek pada proyek konstruksi dibedakan menjadi dua jenis yaitu biaya langsung (Direct Cost) dan biaya tidak langsung (Indirect Cost). Biaya langsung adalah elemen biaya yang memiliki kaitan langsung dengan volume pekerjaan yang tertera dalam item pembayaran atau menjadi komponen permanen hasil akhir proyek. Komponen biaya langsung terdiri dari biaya upah pekerja, operasi peralatan, dan material. Biaya tidak langsung merupakan elemen biaya yang tidak terkait langsung dengan besaran volume komponen fisik hasil akhir proyek, tetapi mempunyai kontribusi terhadap penyelesaian kegiatan atau proyek. Elemen biaya ini umumnya tidak tertera dalam daftar item pembayaran dalam kontrak atau tidak dirinci (Soemardi and Kusumawardani, 2010)(Soemardi, 2010). Setiap proyek konstruksi dengan masing-masing tipe, sifat, \& ukuran pasti memiliki biaya tak langsung (Becker, Jaselskis and El-Gafy, 2014). Elemen biaya yang termasuk dalam kategori biaya tidak langsung antara lain adalah: biaya overhead, pajak (taxes), biaya tak terduga (contingency cost). Beberapa item yang dimaksud biaya overhead adalah: gaji tenaga administrasi, biaya pengelolaan lingkungan, biaya alat komunikasi dan sebagainya.

Dari kedua jenis biaya yang telah dijelaskan, biaya tidak langsung merupakan biaya yang sangat sulit untuk di estimasikan karena tidak mempunyai standar ukuran yang tetap. Rasio persentase biaya tak langsung lebih kecil daripada biaya langsung jika dibandingkan dengan nilai proyek, sehingga perusahaan umumnya memfokuskan untuk mengelola biaya langsung (Becker, Jaselskis and El-Gafy, 2014).

Pada umumnya kontraktor di Kota Tasikmalaya belum melakukan identifikasi biaya tidak langsung secara detail. Sebuah survey pendahuluan telah dilakukan yang melibatkan beberapa responden kontraktor di Kota Tasikmalaya menunjukan bahwa meskipun mereka mengakui besarnya peran biaya tidak langsung dalam keberhasilan proyek, hampir seluruh responden menyatakan mereka tidak mempunyai mekanisme atau kiat-kiat khusus dalam melakukan estimasi biaya tidak langsung tersebut. 
Dari beberapa poin pekerjaan yang biayanya berasal dari biaya tak langsung tersebut terdapat pekerjaan untuk pengelolaan lingkungan. Setiap kegiatan dapat berdampak merusak lingkungan baik komponen fisik-kimia maupun sosial ekonomi, namun dapat diminimalisasi dengan upaya pengelolaan dan pemantauan lingkungan dengan baik (Prasetyo and Alimuddin, 2018). Dampak lingkungan memiliki konsekuensi negatif baik bagi lingkungan maupun individu (Marzouk, El-zayat and Aboushady, 2017). Praktik pengelolaan lingkungan ini sendiri sejalan dengan prinsip pembangunan nasional di Indonesia mengenai pembangunan berkelanjutan. Jika hal ini bisa dilakukan oleh para penyedia jasa khususnya kontraktor kecil dan menengah maka akan meningkatkan produk pembangunan yang ramah lingkungan di Indonesia, karena capaian ramah lingkungan di tingkat praktis masih sangat terbatas untuk jenis proyek tertentu (Ervianto, 2018).

Pekerjaan untuk pengelolaan lingkungan ini dengan menggunakan biaya overhead proyek yang dimana biaya tersebut merupakan biaya tak langsung. Estimasi biaya overhead untuk proyek konstruksi merupakan hal penting dalam manajemen proyek (El-Sawalhi, 2015). Pengelolaan lingkungan sendiri merupakan salah satu hal penting yang harus diperhatikan pada saat kegiatan proyek konstruksi. Lingkungan sendiri sudah menjadi salah satu penilaian kesuksesan proyek konstruksi selain biaya, waktu, \& mutu (Li et al., 2019).

Perhitungan biaya tidak langsung pada kegiatan proyek konstruksi umumnya sangat sulit mengingat adanya ketidakpastian pada penggunaannya. Salah satu unsur dari biaya tidak langsung ini yaitu anggaran untuk pengelolaan dampak lingkungan yang diakibatkan oleh kegiatan proyek konstruksi. Belum diketahuinya persentase biaya pengelolaan lingkungan terhadap nilai proyek di kota Tasikmalaya menjadi salah satu kendala dalam mengestimasikan jumlah biaya tidak langsung secara detail pada setiap kegiatan proyek konstruksi di Kota Tasikmalaya. Berdasarkan permasalahan tersebut maka disusun tujuan penelitian sebagai berikut:

1. Mengidentifikasi pengelolaan dampak lingkungan apa saja yang ditangani oleh pihak kontraktor

2. Menganalisa persentase kisaran biaya maksimal yang dibutuhkan untuk pengelolaan dampak lingkungan fisik berdasarkan nilai proyeknya.

3. Mengidentifikasi pola interaksi besar-kecilnya kisaran biaya pengelolaan lingkungan untuk setiap dampak lingkungan.

Untuk mencapai tujuan tersebut penelitian ini dibatasi sebagai berikut:

1. Proyek yang ditinjau adalah proyek yang ada di Kota Tasikmalaya, baik yang sudah dikerjakan maupun yang masih dikerjakan.

2. Jenis proyek yang diteliti adalah proyek gedung.

3. Proyek yang diteliti adalah proyek dengan nilai total pekerjaan lebih dari sama dengan 5 milyar rupiah.

4. Dampak yang ditinjau adalah dampak fisik yang terjadi pada masa konstruksi.

\section{Metode Penelitian}

Dalam penelitian ini, untuk mencapai tujuan dari penelitian dilakukan tahapan-tahapan penelitian yang menyusun secara keseluruhan proses penelitian mulai dari awal hingga akhir. Tahapan tersebut meliputi proses penyusunan latar 
belakang, perumusan masalah, pra survey, penyusunan tujuan penelitian, pembatasan masalah, pengumpulan data dengan metode wawancara dan kuesioner, pengolahan data, hingga penarikan kesimpulan dari penelitian dan juga pengajuan saran kepada pihak-pihak terkait.

Salah satu tahapan yang paling penting dalam penelitian ini adalah pengumpulan data penelitian, karena melalui data tersebut tujuan penelitian dapat dicapai. Metode pengumpulan data yang dipakai pada penelitian ini diantaranya adalah survey terbatas, metode wawancara semi-terstruktur serta metode kuesioner. Pada penelitian ini, data hasil pra survey digunakan untuk membatasi cakupan penelitian yang disesuaikan dengan tujuan penelitian yang telah dibuat. Setelah adanya pembatasan penelitian maka kemudian dilakukan pengumpulan data penelitian berikutnya. Pengumpulan data penelitian selanjutnya menggunakan dua metode pengumpulan data, yaitu pertama dengan metode wawancara semi-terstruktur dan kedua dengan metode kuesioner. Wawancara adalah Proses percakapan yang dilakukan oleh interviewer dan interviewee dengan tujuan tertentu, dengan pedoman,dan bisa bertatap muka maupun melalui alat komunikasi tertentu (Sarwo, 2016). Dalam penelitian ini, teknik wawancara semi-terstruktur digunakan untuk mengetahui masalah utama dampak lingkungan apa saja yang umumnya terjadi dan diberikan perhatian untuk dilakukan upaya penanganannya oleh pihak kontraktor. Jenis pertanyaan yang diajukan merupakan pertanyaan terbuka namun ada batasan tema dan alur pembicaraan. Informasi yang ingin didapat dari tahapan wawancara ini antara lain profil proyek, jarak lokasi proyek terhadap pemukiman terdekat, dampak lingkungan yang ditangani oleh responden, upaya mitigasi yang dilakukan, biaya yang dikeluarkan untuk upaya mitigasi, waktu dilakukannya upaya mitigasi, serta nilai pekerjaan proyek tersebut. Tahapan berikutnya dalam pengumpulan data primer yaitu wawancara terstruktur dengan menggunakan kuesioner. Pertanyaan pada kuesioner didasarkan pada biaya pengelolaan dampak lingkungan dengan mengacu dampak yang ditanyakan adalah dampak fisik dan yang umumnya dilakukan oleh pihak kontraktor sebagaimana hasil data yang diperoleh sebelumnya pada saat wawancara.

Dari setiap tahapan pengumpulan data dilakukan mikro-analisis dengan mengukur kata kunci yang disebutkan pada setiap jawaban responden untuk mendapatkan jenis dampak yang dikelola pada setiap proyek. Hingga pada tahap akhir analisis data dilakukan pengurutan berdasarkan jumlah biaya yang dikeluarkan pada setiap proyek. Nilai dari interval biaya pengelolaan lingkungan yang di dapatkan dari hasil wawancara kemudian dijadikan rujukan dalam penyusunan kuesioner. Sehingga di dapatkan pula pendekatan dari biaya yang diperlukan untuk pengelolaan setiap dampak dari setiap proyek. Kemudian nilai tersebut di prosentasekan pada nilai proyeknya masing-masing sebagai pendekatan berikutnya untuk melihat pola interaksi biaya pengelolaan dampak lingkungan terhadap nilai proyeknya itu sendiri.

\section{Hasil dan Pembahasan}

Pada tahap ini dilakukan pembahasan dengan menggunakan metode analisis deskriptif mengenai hasil pengumpulan data yang telah dilakukan. Proses pengumpulan data dilakukan dua kali, pertama dengan teknik wawancara dan selanjutnya dengan kuesioner. 


\subsection{Profil Responden}

Pemilihan respoden dilakukan dengan pendekatan terlebih dahulu berdasarkan proyeknya. Selanjutnya didasarkan pada kualifikasi perusahaan dan terakhir personil yang ada di proyek tersebut. Penetapan proyek gedung sebagai subjek penelitian ini didasarkan pada kompetensi kelas perusahaan yang menangani proyek, yang pada umumnya termasuk perusahaan dengan grade menengah dan besar. Diharapkan pada perusahaan dengan grade menengah dan besar pengendalian biaya, mutu serta waktu yang lebih baik dibandingkan perusahaan grade kecil dan tentunya pengelolaan administrasi keuangan yang lebih lengkap.

Pada proses pengumpulan data ini melibatkan beberapa responden yang merupakan project manager yang mewakili proyeknya masingmasing.Wawancara dan kuesioner tersebut diisi oleh responden yang merupakan site manager yang mewakili proyeknya masing-masing. Dari tujuh proyek yang diajukan wawancara dan kuesioner, hanya enam proyek yang memberikan tanggapan. Berikut data profil proyek yang dijadikan objek penelitian yang akan ditampilkan pada Tabel 1 .

Tabel 1 Data peruntukan bangunan pada masing-masing proyek

\begin{tabular}{cc}
\hline Proyek & Peruntukan \\
\hline 1 & Hotel \\
\hline 2 & Hotel \\
\hline 3 & Kantor Swasta \\
\hline 4 & Kantor Dinas Kota \\
\hline 5 & Kantor Pengadilan Agama \\
\hline 6 & Kantor Inspektorat \\
\hline
\end{tabular}

Tabel 2 Tabulasi nilai proyek

\begin{tabular}{cccr}
\hline Proyek & Luas Bangunan $\left(\mathbf{m}^{\mathbf{2}}\right)$ & & \multicolumn{1}{c}{ Nilai Proyek } \\
\hline 1 & 15.205 & $\mathrm{Rp}$ & 114.037 .500 .000 \\
\hline 2 & 7.738 & $\mathrm{Rp}$ & 58.035 .000 .000 \\
\hline 3 & $2.975,97$ & $\mathrm{Rp}$ & 28.271 .715 .000 \\
\hline 4 & 4.320 & $\mathrm{Rp}$ & 19.710 .000 .000 \\
\hline 5 & 1.200 & $\mathrm{Rp}$ & 5.400 .000 .000 \\
\hline 6 & 1.200 & $\mathrm{Rp}$ & 5.400 .000 .000 \\
\hline
\end{tabular}

\subsection{Pengelolaan Lingkungan yang Dilakukan Pada Masa Konstruksi}

Pengelolaan lingkungan pada proyek konstruksi umumnya selalu terjadi dan diperlukan pengendalian untuk meminimalisir pengelolaan yang terjadi. Berdasarkan hasil dari pengumpulan data di dapatkan hasil seperti pada Tabel 3.

Tabel 3 Pengelolaan lingkungan yang diakukan oleh setiap proyek

\begin{tabular}{lcccccc}
\hline $\begin{array}{l}\text { Pengelolaan Lingkungan } \\
\text { untuk Dampak }\end{array}$ & Proyek & Proyek & Proyek & Proyek & Proyek & Proyek \\
\hline Kebisingan & $\mathbf{1}$ & $\mathbf{2}$ & $\mathbf{3}$ & $\mathbf{4}$ & $\mathbf{5}$ & $\mathbf{6}$ \\
\hline Lingkungan kotor & $\checkmark$ & $\checkmark$ & $\checkmark$ & $\checkmark$ & $\checkmark$ & $\checkmark$ \\
\hline kualitas udara & $\checkmark$ & $\checkmark$ & $\checkmark$ & $\checkmark$ & $\checkmark$ & $\checkmark$ \\
\hline Kualitas \& Kuantitas air & $\checkmark$ & & & & & \\
\hline Getaran & $\checkmark$ & $\checkmark$ & $\checkmark$ & $\checkmark$ & $\checkmark$ & $\checkmark$ \\
\hline Akses jalan & $\checkmark$ & $\checkmark$ & $\checkmark$ & $\checkmark$ & $\checkmark$ & $\checkmark$ \\
\hline
\end{tabular}

Studi Mengenai Biaya Pengelolaan Lingkungan Pada Masa Konstruksi - Agi R. 127 Hendardi 
Berdasarkan hasil wawancara, jenis pengelolaan lingkungan yang dominan dikerjakan hanya empat jenis pengelolaan dari enam jenis pengelolaan dampak fisik lingkungan yang diteliti. Empat jenis pengelolaan lingkungan tersebut yakni pengelolaan dampak kebisingan, pengelolaan dampak kualitas dan kuantitas air, pengelolaan dampak lingkungan kotor, dan pengelolaan dampak akses jalan.

\subsection{Biaya Pengelolaan Lingkungan Pada Masa Konstruksi}

Berdasarkan hasil kuesioner, setelah disesuaikan dengan nilai kontrak setiap proyek, didapatkan data jumlah biaya pengelolaan lingkungan dalam persentase nilai kontrak masing-masing proyek. kisaran total biaya ini didapatkan dengan cara menghitung kisaran biaya yang diperlukan untuk pengelolaan 4 jenis dampak lingkungan dari setiap proyek. Berikut akan disajikan kisaran biaya yang dikeluarkan oleh pihak kontraktor untuk kegiatan pengelolaan lingkungan.

Tabel 4 Persentase biaya untuk pengelolaan dampak kebisingan.

\begin{tabular}{cccc}
\hline Proyek & \multicolumn{2}{c}{ Pengelolaan Dampak Kebisingan } \\
\hline 1 & $0,0176 \%$ & - & $0,0220 \%$ \\
\hline 2 & $0,0340 \%$ & - & $0,0425 \%$ \\
\hline 3 & $0,0170 \%$ & - & $0,0340 \%$ \\
\hline 4 & $0,0000 \%$ & - & $0,0050 \%$ \\
\hline 5 & $0,0200 \%$ & - & $0,1000 \%$ \\
\hline 6 & $0,1000 \%$ & - & $0,2000 \%$ \\
\hline
\end{tabular}

Tabel 5 Persentase biaya untuk pengelolaan dampak kuantitas \& kualitas air.

\begin{tabular}{cccc} 
Proyek & \multicolumn{2}{c}{ Pengelolaan Dampak Kualitas \& Kuantitas Air } \\
\hline 1 & $0,0132 \%$ & - & $0,0176 \%$ \\
\hline 2 & $0,0255 \%$ & - & $0,0340 \%$ \\
\hline 3 & $0,0170 \%$ & - & $0,0340 \%$ \\
\hline 4 & $0,1000 \%$ & - & $0,1250 \%$ \\
\hline 5 & $0,4000 \%$ & - & $0,5000 \%$ \\
\hline 6 & $0,0200 \%$ & - & $0,1000 \%$ \\
\hline
\end{tabular}

Tabel 6 Persentase biaya untuk pengelolaan dampak lingkungan kotor.

\begin{tabular}{cccc}
\hline Proyek & \multicolumn{3}{c}{ Pengelolaan Dampak Lingkungan Kotor } \\
\hline 1 & $0,0132 \%$ & - & $0,0176 \%$ \\
\hline 2 & $0,0170 \%$ & - & $0,0255 \%$ \\
\hline 3 & $0,0340 \%$ & - & $0,0510 \%$ \\
\hline 4 & $0,0050 \%$ & - & $0,0250 \%$ \\
\hline 5 & $0,0000 \%$ & - & $0,0200 \%$ \\
\hline 6 & $0,0200 \%$ & - & $0,1000 \%$ \\
\hline
\end{tabular}

Tabel 1 Persentase biaya yang dikeluarkan untuk pengelolaan akses jalan.

\begin{tabular}{cccc}
\hline Proyek & \multicolumn{3}{c}{ Pengelolaan Dampak Akses Jalan } \\
\hline 1 & $0,0176 \%$ & - & $0,0220 \%$ \\
\hline 2 & $0,0255 \%$ & - & $0,0340 \%$ \\
\hline 3 & $0,0340 \%$ & - & $0,0510 \%$ \\
\hline 4 & $0,1000 \%$ & - & $0,1250 \%$ \\
\hline 5 & $0,2000 \%$ & - & $0,3000 \%$ \\
\hline 6 & $0,1000 \%$ & - & $0,2000 \%$ \\
\hline
\end{tabular}


Dari empat jenis pengelolaan lingkungan tersebut, kemudian dihitung akumulasi dari jumlah dari kisaran pengelolaan seluruh dampak lingkungan dalam persentase nilai proyek sehingga di dapatkan hasil sebagai berikut.

Perhitungan nilai kisaran biaya total pengelolaan lingkungan dilakukan dengan menjumlahkan nilai batas miinimal dengan batas minimal lainnya dan nilai batas maksimal dengan batas maksimal yang lainnya sesuai dengan data yang ada. Contoh perhitungan proyek 6 batas minimal dari kisaran total biaya pengelolaan lingkungan sebagai berikut

$$
\begin{aligned}
& \text { Batas min imal }=B m \\
& \begin{array}{l}
\text { Bm }=B m_{\text {kebisingan }}+B m_{\text {kuantitas\&kualitasAir }}+B m_{\text {LingkunganKotor }}+B m_{\text {Akses Jalan }} \\
B m=0,1+0,02+0,02+0,1=0,24 \%
\end{array}
\end{aligned}
$$

Maka batas minimal kisaran biaya total untuk pengelolaan lingkungan adalah 0,24 \% dari nilai kontrak Proyek 6. Begitu pula perhitungan untuk batas maksimal kisaran biaya total untuk pengelolaan lingkungan pada proyek 6 , setiap batas maksimal dari kisaran biaya yang digunakan untuk masing-masing dampak lingkungan tersebut.

Setelah dilakukan perhitungan dari setiap total biaya pengelolaan lingkungan di setiap proyek, di dapatkan kisaran persentase total biaya yang diperlukan untuk mengelola dampak lingkungan pada masa konstruksi gedung sebagai berikut,

Tabel 8 Kisaran persentase total biaya untuk pengelolaan dampak lingkungan berdasarkan nilai proyeknya

\begin{tabular}{crll}
\hline Proyek & \multicolumn{3}{c}{ Total Biaya $(\%)$} \\
\hline Proyek 1 & 0,0616 & - & 0,0792 \\
\hline Proyek 2 & 0,102 & - & 0,136 \\
\hline Proyek 3 & 0,102 & - & 0,17 \\
\hline Proyek 4 & 0,155 & - & 0,23 \\
\hline Proyek 5 & 0,62 & - & 0,92 \\
\hline Proyek 6 & 0,24 & - & 0,6 \\
\hline
\end{tabular}

Berdasarkan hasil pengumpulan data, dapat dilihat bahwa nilai persentase biaya pengelolaan lingkungan pada setiap proyek memiliki kecenderungan semakin tinggi nilai kontrak suatu proyek, semakin kecil persentase biaya pengelolaan lingkungannya. Namun setelah dilakukan analisis lebih lanjut dengan mengubah nilai persentase tersebut ke dalam nilai rupiah dengan cara mengalikannya terhadap masing-masing nilai kontrak setiap proyek maka didapatkan hasil sebagai berikut.

Tabel 9 Kisaran biaya untuk pengelolaan lingkungan di setiap proyek

\begin{tabular}{ccccccccc}
\hline Proyek & \multicolumn{2}{c}{ Total Biaya (\%) } & \multicolumn{5}{c}{ Total Biaya (Rp) } \\
\hline Proyek 1 & 0,0616 & - & 0,0792 & $\mathrm{Rp}$ & 70.840 .000 & - & $\mathrm{Rp}$ & 91.080 .000 \\
\hline Proyek 2 & 0,102 & - & 0,136 & $\mathrm{Rp}$ & 61.200 .000 & - & $\mathrm{Rp}$ & 81.600 .000 \\
\hline Proyek 3 & 0,102 & - & 0,17 & $\mathrm{Rp}$ & 30.600 .000 & - & $\mathrm{Rp}$ & 51.000 .000 \\
\hline Proyek 4 & 0,155 & - & 0,23 & $\mathrm{Rp}$ & 31.000 .000 & - & $\mathrm{Rp}$ & 46.000 .000 \\
\hline Proyek 5 & 0,62 & - & 0,92 & $\mathrm{Rp}$ & 31.000 .000 & - & $\mathrm{Rp}$ & 46.000 .000 \\
\hline Proyek 6 & 0,24 & - & 0,6 & $\mathrm{Rp}$ & 12.000 .000 & - & $\mathrm{Rp}$ & 30.000 .000 \\
\hline
\end{tabular}

Studi Mengenai Biaya Pengelolaan Lingkungan Pada Masa Konstruksi - Agi R. Hendardi 
Setelah dilakukan perhitungan kedalam rupiah dapat terlihat bahwa semakin besar nilai kontrak suatu proyek maka biayanya pun semakin besar. Hal ini berbanding terbalik dengan kecenderungan ketika nilai biaya tersebut masih dikonversikan dalam persentase. Berdasarkan hasil wawancara, hal ini terjadi karena ketika semakin besar nilai kontrak suatu proyek maka semakin banyak pula pekerjaan yang harus dilakukan, semakin banyak pekerjaan yang dilakukan maka semakin besar dan semakin lama pula dampak lingkungan yang terjadi sehingga biaya yang diperlukan untuk mengelola dampak tersebut akan semakin besar pula.

\section{Kesimpulan dan Saran}

\subsection{Kesimpulan}

Dari hasil analisis dan pembahasan maka didapatkan beberapa poin kesimpulan yaitu:

1. Pengelolaan dampak lingkungan yang ditangani oleh pihak kontraktor adalah pengelolaan dampak kebisingan, pengelolaan dampak kuantitas \& kualitas air, pengelolaan dampak lingkungan kotor, dan pengelolaan dampak akses jalan.

2. Biaya pengelolaan dampak lingkungan untuk setiap proyek Gedung di Kota Tasikmalaya maksimal sekitar $0,92 \%$ dari nilai proyeknya sendiri.

3. Nilai persentase biaya pengelolaan lingkungan pada setiap proyek memiliki pola interaksi semakin tinggi nilai kontrak suatu proyek, semakin kecil persentase kisaran biaya pengelolaan lingkungannya. Setelah dilakukan perhitungan kedalam rupiah dapat terlihat bahwa semakin besar nilai kontrak suatu proyek maka kisaran biayanya pun semakin besar. Hal ini berbanding terbalik dengan kecenderungan ketika nilai biaya tersebut masih dikonversikan dalam persentase. Faktor-faktor yang mempengaruhi pola interaksi dari kisaran biaya pengelolaan lingkungan tergantung pada karakteristik proyek yang berupa lokasi proyek, nilai proyek, serta spesifikasi pekerjaan pada masingmasing proyek.

\subsection{Saran}

Dari penelitian yang telah dilakukan terdapat beberapa saran untuk penelitian lanjutan diantaranya diperlukan jumlah objek penelitian yang lebih banyak untuk mendapatkkan pola interaksi yang lebih baik dengan analisis yang lebih objektif pada setiap pengelolaan dampak lingkungan. Untuk penelitian selanjutnya dampak yang diteliti sebaiknya tidak hanya dampak fisik saja, karena masih terdapat jenis dampak lain yang diakibatkan oleh adanya kegiatan proyek konstruksi. Pada penelitian serupa di masa mendatang, disarankan untuk menambah faktor-faktor pengukuran dari dampak lingkungan untuk mendapatkan pola interaksi dari biaya pengelolaan lingkungan.

\section{Ucapan Terima Kasih}

Ucapan terima kasih penulis sampaikan kepada Allah SWT atas rahmat dan karunianya penulis dapat menyelesaikan penelitian ini, serta kepada rekan-rekan yang telah membantu dalam penyusunan penelitian kali ini. 


\section{Daftar Kepustakaan}

Becker, T. C., Jaselskis, E. J. and El-Gafy, M, 2014, Improving predictability of construction project outcomes through intentional management of indirect construction costs, Journal of Construction Engineering and Management. American Society of Civil Engineers (ASCE), 140(6). doi: 10.1061/(ASCE)CO.1943-7862.0000845

Chan, C. T. W, 2012, The principal factors affecting construction project overhead expenses: An exploratory factor analysis approach, Construction Management and Economics, 30(10). doi: 10.1080/01446193.2012.717706

El-Sawalhi, N. I, 2015, An Overhead Costs Assessment for Construction Projects at Gaza Strip, American Journal of Civil Engineering, 3(4). doi: 10.11648/j.ajce.20150304.11

Ervianto, W. I, 2018, Studi Tentang Daya Saing Penyedia Jasa Konstruksi Dalam Perspektif Konstruksi Berkelanjutan Di Indonesia, Jurnal Ilmiah Teknik Sipil, pp. 7-15. doi: 10.24843/JITS.2018.v22.i01.p02

$\mathrm{Li}$, Y. et al, 2019, The impact of project environmental practices on environmental and organizational performance in the construction industry, International Journal of Managing Projects in Business. Emerald Group Publishing Ltd., 13(2), pp. 367-387. doi: 10.1108/IJMPB-07-2018-0137

Marzouk, M., El-zayat, M. and Aboushady, A, 2017, Assessing environmental impact indicators in road construction projects in developing countries, Sustainability (Switzerland). MDPI AG, 9(5). doi: 10.3390/su9050843

Prasetyo, D. and Alimuddin, 2018, Pembangunan Pembangkit Listrik Tenaga Minihidro, Seminar Nasional Sains dan Teknologi, pp. 1-11

Sarwo, E. F. R, 2016, Teori Wawancara Psikodignostik, PT Leutika Nouvalitera, PT Leutika Nouvalitera. Available at: https://books.google.co.id/books?hl=id\&lr=\&id=uS96DwAAQBAJ\&oi=fnd $\& p g=$ PA1\&dq=teknik+pengumpulan+data+wawancara\&ots=zHXayNBd5b \&sig=Pu8f_NzSHiMSTV2Nhw7ofiDccw8\&redir_esc=y\#v=onepage\&q=te knik pengumpulan data wawancara\& $\mathrm{f}=\mathrm{false}$

Soemardi, B. W, 2010, Rancangan Kuesioner Profil Responden, 4(KoNTekS 4), pp. 2-3.

Soemardi, BW. and Kusumawardani, R. G, 2010, Studi Praktek Estimasi Biaya Tidak Langsung Pada Proyek Konstruksi, Konferensi Nasional Teknik Sipil. 